Penelitian

\title{
Transmisi Strain Wuchereria bancrofti Periodik Nokturnal oleh Culex quinquefasciatus di Kota Pekalongan
}

\author{
(Transmission of the nocturnal periodic strain of Wuchereria bancrofti \\ by Culex quinquefasciatus in Pekalongan City)
}

\author{
Tri Ramadhani', Upik Kesumawati Hadi', Susi Soviana ${ }^{2}$, Zubaidah Irawati ${ }^{3}$
}

'Balai Penelitian dan Pengembangan Kesehatan Banjarnegara

\author{
${ }^{2}$ Laboratorium Entomologi, Departemen Parasitologi dan Entomologi Kesehatan, Fakultas Kedokteran Hewan Bogor, \\ JI Agatis Kampus IPB Darmaga, Bogor, 16680 \\ ${ }^{3}$ Pusat Aplikasi Teknologi Isotop dan Radiasi (PATIR) Badan Atom Tenaga Nuklir (BATAN) Indonesia, \\ JI Jalan Lebak Bulus Raya No. 49, North Jakarta 12440 \\ *Penulis untuk korespondensi: 3rdhani@gmail.com \\ Diterima 23 Desember 2018, Disetujui 13 Maret 2019
}

\begin{abstract}
ABSTRAK
Wuchereria bancrofti dikenal sebagai penyebab filariasis limfatik di Kota Pekalongan. Kegiatan ini dilakukan untuk mencari upaya dalam pengendalian penularan filariasis limfatik yang lebih efektif dan efisien. Tujuan penelitian untuk mendiskripsikan perilaku mikrofilaria Wuchereria bancrofti yang ditularkan oleh Culex quinquefasciatus. Uji periodisitas dilakukan pada enam orang relawan yang positif mengandung mikrofilaria hasil survei darah. Pengambilan darah dilakukan setiap dua jam sekali selama 24 jam (12 kali pengamatan). Uji periodisitas cacing filaria menggunakan formula Aikat dan Das . Hasil survei darah menunjukkan dari 500 sampel darah sebanyak 17 orang positif mikrofilaria ( $\mathrm{mf}$ rate $=3,4 \%$ ). Sebagian besar mikrofilaria muncul antara pukul 22.6'36" sampai 03.56'24" yang menggambarkan periodisitas mikrofilaria Wuchereria bancrofti yang nokturnal. Kasus filariasis limfatik memiliki gelombang yang harmonik atau sirkardian dengan indeks periodisitas lebih dari $100 \%$. Hasil penelitian ini akan sangat membantu dalam mengevaluasi dan memantau program pengobatan massal yang sedang berjalan untuk eliminasi filarisis limfatik di Kota Pekalongan.
\end{abstract}

Kata kunci: periodisitas, Wuchereria bancrofti, periodik nokturnal

\begin{abstract}
Wuchereria bancrofti is known as the cause of lymphatic filariasis in Pekalongan City. This activity is conducted to seek efforts in controlling the transmission of lymphatic filariasis more effectively and efficiently. The objective of the study was to describe the behavior of Wuchereria bancrofti microfilariae transmitted by Culex quinquefasciatus. Periodicity test was performed on six positive volunteers containing microfilariae of blood survey. Blood collection is done every two hours for 24 hours ( 12 observations). Test the periodicity of filaria worm using Aikat and Das formulas. The blood survey results showed from 500 samples as many as 17 people positive microfilariae ( $\mathrm{mf}$ rate $=3.4 \%$ ). Most microfilariae appear between $22.6^{\prime} 36^{\prime \prime}$ to $03.56^{\prime} 24^{\prime \prime}$ describing a nocturnal periodicity of circulating Wuchereria bancrofti microfilariae.The case of lymphatic filariasis has a harmonic or circular wave with a periodicity index of more than $100 \%$. The results of this study will be helpful in evaluating and monitoring MDA for elimination of lymphatic filariasis in Pekalongan City.
\end{abstract}

Keywords: periodicity, Wuchereria bancrofti, periodic nocturnal 


\section{PENDAHULUAN}

Filariasis limfatik adalah penyakit yang disebabkan oleh cacing jaringan filarial jenis Wuchereria bancrofti, Brugia malayi, dan Brugia timori. Distribusi penyakit ini hampir di seluruh wilayah Indonesia dan di beberapa daerah dengan tingkat endemisitas cukup tinggi. Menurut Pusat Data dan Informasi Kementerian Kesehatan RI tahun 2016, sampai saat ini penderita di daerah endemis filariasis pada umumnya adalah daerah dataran rendah, terutama pedesaan, pantai, pedalaman, persawahan, rawarawa, dan hutan. Secara umum filariasis bancrofti tersebar di Sumatra, Jawa, Kalimantan, Sulawesi, Nusa Tenggara, Maluku dan Papua. Daerah endemis Wuchereria bancrofti dibedakan menjadi tipe pedesaan dan tipe perkotaan berdasarkan vektor yang menularkan. Wuchereria tipe pedesaan ditularkan oleh vektor Anopheles, Culex dan Aedes sedangkan tipe perkotaan vektornya Culex quinquefasciatus (Kemenkes RI, 2010).

Kota Pekalongan merupakan salah satu daerah endemis filariasis limfatik di Provinsi Jawa Tengah. Kasus filariasis di Kota Pekalongan mulai ditemukan sejak tahun 2002 dan pada tahun 2004 mulai dilakukan Survei Darah Jari (SDJ sebagai langkah awal dalam upaya eliminasi filariasis di Kota Pekalongan. Berdasarkan survei darah jari (SDJ) yang telah dilakuka mulai tahun 2004 sampai dengan tahun 2010 jumlah kasus klinis yang ditemukan sebanyak 172 kasus, sedangkan kasus kronis sebanyak 21 kasus. Pada tahun 2010, kasus filariasis di Kota Pekalongan berjumlah 63 penderita yang terdiri atas 55 kasus klinis dan 8 kasus kronis. Pada tahun 2011 Kota Pekalongan mengalami peningkatan jumlah kasus menjadi 117 penderita yang terdiri dari 110 kasus klinis dan 7 kasus kronis. Pada tahun 2012 jumlah kasus filariasis menjadi 66 penderita yang terdiri dari 59 kasus klinis dan 7 kasus kronis yang diambil dari sampel 4 kelurahan yaitu Kelurahan Kertoharjo, Jenggot, Pabean dan Banyurip (Dinkes Kota Pekalongan, 2012). Kecenderungan penyebaran penyakit filariasis berkaitan erat dengan semakin meningkatnya kepadatan penduduk, sanitasi lingkungan yang buruk serta keberadaan tempat perkembanganbiakan nyamuk.

Berdasarkan perilaku mikrofilaria , filarial limfatik dapat dibedakan dalam berbagai varian intra spesifik yaitu periodik nokturnal, subperiodik noktural, B.malayi),subperiodik diurnal serta non periodik. Pada periodik diurna, mikrofilaria ditemukan dalam darah tepi terutama pada siang hari dan mencapai puncak pada pukul 10.00-13.00. Pada subperiodik diurna mikrofilaria ditemukan di dalam darah tepi selama 24 jam, tetapi kepadatan mikrofilaria cenderung lebih banyak ditemukan pada siang hari. Pada mikrofilaria yang bersifat nokturnal, stadium mikrofilaria ditemukan di dalam darah tepi terutama pada malam hari dan mencapai puncaknya pada pukul 22.00-01.00, sementara mikrofilaria yang mempunyai sifat subperiodik nokturnal, berada dalam darah tepi selaFma 24 jam tetapi mencapai puncaknya pada pukul 18.00-22.00. Menurut Sasa (1976) dan Partono (1978) mikrofilaria yang sifatnya nonperiodik, stadium mikrofilaria dapat ditemukan di dalam darah tepi sepanjang waktu dan tidak ada puncak kepadatan.

Kota Pekalongan termasuk daerah endemis Wuchereria bancrofti tipe perkotaan (urban) dengan kondisi lingkungan yang kumuh, padat penduduknya dan terdapat genangan air kotor dari pencemaran industri rumah tangga (batik). Mata pencaharian sebagian besar penduduk sebagai pengrajin batik (industri rumah tangga) dan petani. Letak Kelurahan Pabean yang berdekatan dengan pantai, mengakibatkan suhu udara antara $29^{\circ} \mathrm{C}-31^{\circ} \mathrm{C}$ (Kota Pekalongan 2015). Porositas/peresapan tanah di wilayah Pabean tergolong rendah schingga mengakibatkan keberadaan genangan air bertahan lebih lama. Pada saluran air limbah industri rumah tangga terutama limbah pewama batik dan saluran irigasi masih banyak ditemukan sampah menumpuk yang mengakibatkan air sulit mengalir. Kondisi lingkungan sebagaimana tersebut di atas sangat disukai sebagai tcmpat perkembangbiakan nyamuk penular filariasis (Sunaryo 2008). Kondisi tersebut yang mengakibatkan transmisi filariasis limfatik masih berlangsung, hal ini diperkuat dengan masih ditemukannya larva cacing filariasis (stadium L3) pada nyamuk Culex quinquefasciatus (Ramadhani et al. 2010).

\section{BAHAN DAN METODE}

Penelitian ini merupakan penelitian observasional dengan rancangan cross sectional. Kelurahan Pabean dipilih sebagai lokasi penelitian dengan pertimbangan termasuk empat Kelurahan dengan masalah filariasis limfatik dengan $\mathrm{mf}$ rate lebih dari $1 \%$ (Dinkes Kota Pekalongan 2012). Kelurahan Pabean merupakan daerah perkotaan dengan lingkungan pemukiman yang padat penduduknya dan banyaknya genangan air baik dari limbah rumah tangga, pewarnaan kain batik maupun rob air laut. Porositas tanah yang rendah mengakibatkan air tergenang dalam waktu relatif lama. 
Kegiatan pengambilan darah jari dilakukan malam hari pada pukul 19.00 - 24.00 WIB terhadap 500 orang penduduk di Kelurahan Pabean. Seluruh masyarakat yang telah dikumpulkan terlebih dahulu diberi penjelasan tentang cara pengambilan dan pemeriksaan sedian darah jari yang akan dilakukan, maanfaat serta meminta kesediaan masyarat untuk diperiksa. Masyarakat yang telah menandatangani informed concent dan mendaftarkan diri kemudian diberi pertanyaan singkat apakah pernah mempunyai riwayat demam. Masyarakat yang telah mendaftar kemudian diambil darahnya pada ujung jari dan dibuat sediaan darah tebal sesuai dengan SOP dari Depertemen Kesehatan (Dep Kes RI 2002).

\section{HASIL PENELITIAN}

Berdasarkan morfologi mikrofilaria yang didapatkan, parasit penyebabnya dapat diidentifikasikan sebagai Wuchereria bancrofti yang secara epidemiologi termasuk tipe perkotaan. Adapun ciricirinya adalah memiliki selubung, pada ruang kepala perbandingan panjang sama dengan lebarnya, tidak ada inti pada ujung ekor dan lekukan badannya halus (WHO 2013).

Hasil pemeriksaan menunjukkan keberadaan mikrofilaria dalam darah tepi tidak selalu dijumpai pada setiap periode pemeriksaan selama 24 jam, akan tetapi lebih cenderung ditemukan pada malam hari setelah pukul 20.00 dan yang tertinggi pada pukul 22.00. Sementara hari mikrofilaria hanya pada 3 dan 4 (Grafik 1). Untuk mengetahui sifat periodisitasnya dilakukan perhitungan analisis statistik menurut cara Aikat dan Das yaitu dengan rumus hubungan antara kepadatan mikrofilaria $(\mathrm{Y})$ dengan waktu pengambilan darah (h), yang dihitung dengan menggunakan formulasi sebagai berikut :

$\mathrm{Y}=\mathbf{m}+\mathbf{b} \cos 15 \mathrm{~h}+\mathbf{c} \sin 15 \mathrm{~h}$. dengan ketentuan (Y) adalah kepadatan mikrofilaria pada 12 kali, (n) pemeriksaan darah selama jam, (m) adalah ratarata jumlah mikrofilaria per pengambilan volume darah $\left(20 \mathrm{~mm}^{3}\right)$; (h) adalah waktu pengambilan darah dan (K) adalah puncak kepadatan mikrofilaria.

Pada Tabel 1 dapat dilihat bahwa jumlah mikrofilaria keseluruhan ( $\mathrm{Y}$ ) berturut-turut dari penderita pertama sampai keenam adalah 460 ekor, 19 ekor, 272 ekor, 330 ekor, 63 ekor dan 153 ekor. Jumlah mikrofilaria terendah adalah penderita kedua sedangkan yang tertinggi adalah penderita pertama. Untuk mempermudah uraian proses perhitungan statistik, berikut dijelaskan proses untuk penderita pertama.

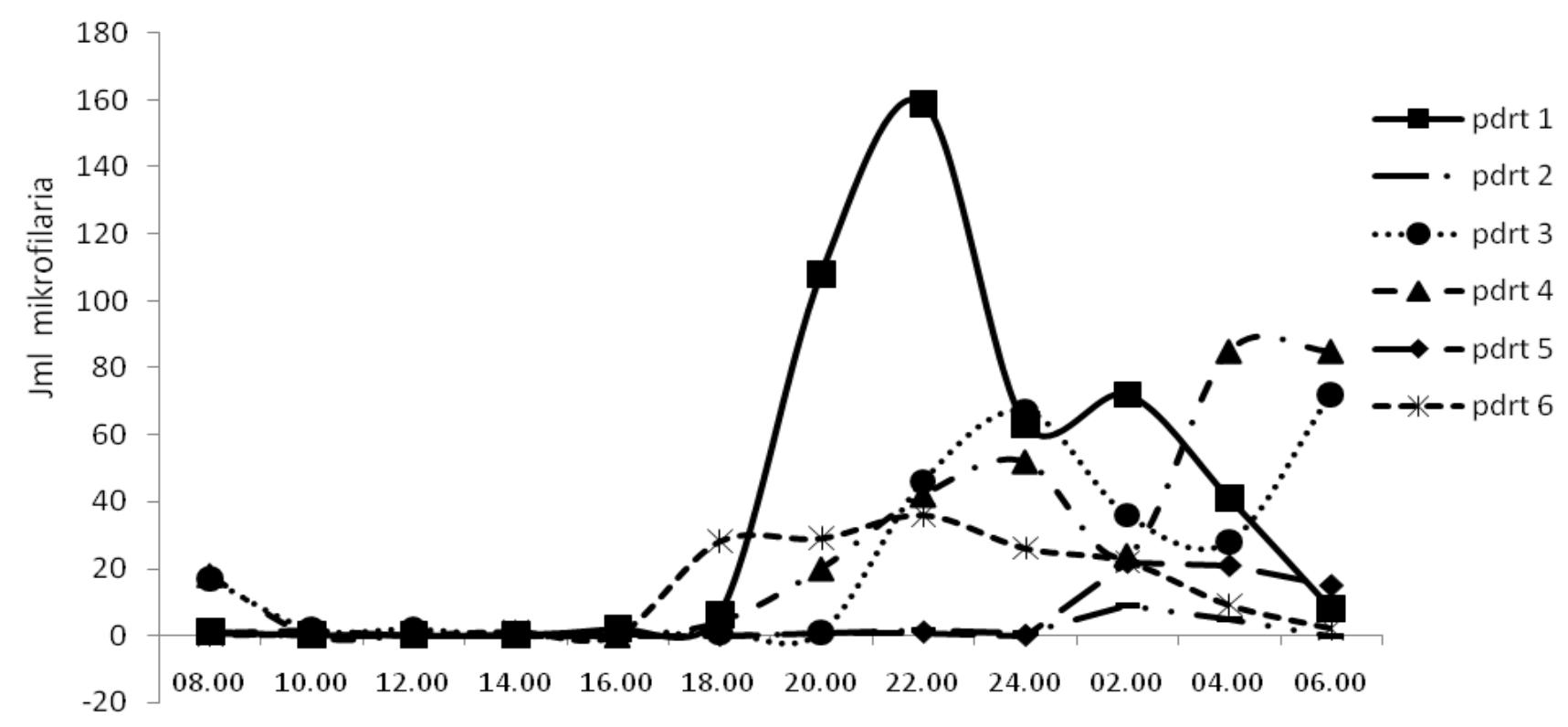

Waktu pengambilan darah

Grafik 1 Fluktuasi kepadatan mikrofilaria Wuchereria bancroftiper $20 \mathrm{~mm}$ pada enam penderita di Kelurahan Pabean Kec. Pekalongan Utara Kota Pekalongan 
Tabel 1 Jumlah mikrofilaria yang ditemukan pada enam penderita positif filariasis limfatik selama 24 jam

\begin{tabular}{|c|c|c|c|c|c|c|}
\hline \multirow{2}{*}{$\begin{array}{l}\text { Waktu pengambilan } \\
\text { darah }\end{array}$} & \multicolumn{6}{|c|}{ Kepadatan mikrofilaria pada penderita } \\
\hline & 1 & 2 & 3 & 4 & 5 & 6 \\
\hline 08.00 & 1 & 1 & 17 & 18 & 1 & 0 \\
\hline 10.00 & 0 & 0 & 2 & 0 & 2 & 0 \\
\hline 12.00 & 0 & 0 & 2 & 0 & 0 & 0 \\
\hline 14.00 & 0 & 0 & 0 & 0 & 0 & 1 \\
\hline 16.00 & 2 & 0 & 0 & 0 & 0 & 0 \\
\hline 18.00 & 6 & 0 & 1 & 4 & 0 & 28 \\
\hline 20.00 & 108 & 1 & 1 & 20 & 1 & 29 \\
\hline 22.00 & 159 & 2 & 46 & 42 & 1 & 36 \\
\hline 24.00 & 63 & 1 & 67 & 52 & 0 & 26 \\
\hline 02.00 & 72 & 9 & 36 & 24 & 22 & 22 \\
\hline 04.00 & 41 & 5 & 28 & 85 & 21 & 9 \\
\hline 06.00 & 8 & 0 & 72 & 85 & 15 & 2 \\
\hline Total & 460 & 19 & 272 & 330 & 63 & 153 \\
\hline
\end{tabular}

Analisis statistik (Aikat dan Das,1976) data survei periodisitas mikrofilaria ini secara keseluruhan dilakukan pada ke enam penderita mikrofilaremia Wuchereria bancrofti. Hasil analisis statistik dapat diketahui sifat parasit yang menunjukkan sifat periodik nokturna. Untuk mempermudah proses perhitungan statistik, pada Tabel 2 dijelaskan proses untuk penderita pertama.

Dari Tabel 2 dan 3 diketahui mikrofilaria ratarata $(\mathrm{m})$ adalah 38,33. Harga (b) yaitu $+56,01$; harga (c) yaitu $-16,73$. Adapun harga (a) dapat dihitung dari $a^{2}=b^{2}+c^{2}$, yaitu 58,453 . Harga tan $15 k^{\circ}$ (harga c dibagi b) yaitu -0,30. Hasil perhitungan didapatkan harga aksis minus dan ordinat plus, dengan demikian puncak kepadatan mikrofilaria (K) terletak pada kuadran ke 4, dan dapat dihitung dengan cara $360^{\circ}$ dikurangi 16,69 dan dibagi 15 dan hasilnya adalah pukul 22.53'24".

Untuk tes kemaknaan dapat dihitung harga $F$, sifat gelombang yang diperoleh dikatakan harmonik, ritmik atau sirkadian apabila harga $\mathrm{F}$ lebih besar dari harga $F 5 \%$ teoritis $(F=4,26)$ dengan derajat kebebasan 2 dan ( $n-3)$ dan indeks periodisitas (D) sekitar 90\%, sebaliknya sifat gelombang dikatakan non harmonik apabila harga $\mathrm{F}$ yang diperoleh lebih kecil dan gelombang menunjukkan sifat subperiodik apabila indeks periodisitas (D) jauh rendah yaitu sekitar 30\%. Dari Tabel 3 diketahui $\mathrm{F}$ pada penderita pertama sebesar 18,92 (lebih besar dari 4,26 ) dan indeks periodisitas (D) sebesar 152,49\%.
Hasil analisis statistik pemeriksaan darah selama 24 jam pada keenam penderita mikrofilaremia di Kelurahan Pabean menunjukkan bahwa pada dasarnya W.bancrofti di daerah tersebut bersifat nokturnal (Tabel 3) dan mempunyai pola yang harmonik. Sifat ini ditunjukkan pada semua penderita dengan harga $\mathrm{F}$ diatas harga $\mathrm{F} 5 \%$, sifat nokturnal juga dipertegas dengan melihat harga $\mathrm{K}$ yang relatif pendek intervalnya yaitu malam hari mulai pukul 22.00-03.00. Waktu puncak kepadatan mikrofilaria menunjukkan perbedaan yang signifikan antara malam dan siang hari. Dari hasil analisis penelitian ini terlihat bahwa parasit filaria menyesuaikan perilaku aktifitas menggigit dari nyamuk sebagai vektornya yaitu Culex quinquefasciatus yang cenderung menggigit pada malam hari (Grafik 2).

\section{PEMBAHASAN}

Kejadian filariasis melibatkan banyak faktor yang kompleks yaitu cacing filaria, manusia sebagai inang, nyamuk sebagai vektor, lingkungan biologik, sosial budaya serta perilaku masyarakat (Santoso 2010). Kelurahan Pabean Kota Pekalongan merupakan daerah endemis filariasis limfatik yang disebabkan cacing Wuchereria bancrofti yang masuk tipe perkotaan dengan vektor utama $C x$. quinquefasciatus. 
Tabel 2 Perhitungan statistik hasil pemeriksaan periodisitas mikrofilaria pada penderita pertama di Kelurahan Pabean Kota Pekalongan

\begin{tabular}{cllllll}
\hline $\begin{array}{c}\text { Waktu } \\
\text { pengambilan darah }\end{array}$ & \multicolumn{1}{c}{$\operatorname{Cos} 15 \mathrm{~h}$} & Sin $15 \mathrm{~h}$ & $\mathrm{Jml} \operatorname{mf}(\mathrm{Y})$ & $\mathrm{Y}^{2}$ & $\mathrm{Y} \cos 15 \mathrm{~h}$ & $\mathrm{Y} \sin 15 \mathrm{~h}$ \\
\hline 08.00 & $-0,5$ & 0,866 & 1 & 1 & $-0,5$ & 0,866 \\
10.00 & $-0,866$ & 0,5 & 0 & 0 & 0 & 0 \\
12.00 & -1 & 0 & 0 & 0 & 0 & 0 \\
14.00 & $-0,866$ & $-0,5$ & 0 & 0 & 0 & 0 \\
16.00 & $-0,5$ & $-0,866$ & 2 & 4 & -1 & $-1,732$ \\
18.00 & 0 & -1 & 6 & 36 & 0 & -6 \\
20.00 & 0,5 & $-0,866$ & 108 & 11664 & 54 & $-93,528$ \\
22.00 & 0,866 & $-0,5$ & 159 & 25281 & 137,694 & $-79,5$ \\
24.00 & 1 & 0 & 63 & 3969 & 63 & 0 \\
02.00 & 0,866 & 0,5 & 72 & 5184 & 62,352 & 36 \\
04.00 & 0,5 & 0,866 & 41 & 1681 & 20,5 & 35,506 \\
06.00 & 0 & 1 & 8 & 64 & 0 & 8 \\
Total & & & 460 & 47884 & 336,046 & $-100,388$ \\
\hline
\end{tabular}

Tabel 3 Analisis statistik hasil pemeriksaan periodisitas mikrofilaria pada 6 penderita di Kelurahan Pabean Kota Pekalongan

\begin{tabular}{|c|c|c|c|c|c|c|}
\hline \multirow{2}{*}{$\begin{array}{l}\text { Analisis } \\
\text { statistik }\end{array}$} & \multicolumn{6}{|c|}{ Penderita filariasis } \\
\hline & P1 & $\mathrm{P} 2$ & P3 & $\mathrm{P} 4$ & P5 & P6 \\
\hline $\mathrm{Y}$ & 460 & 19 & 272 & 330 & 63 & 153 \\
\hline $\mathrm{Y}^{2}$ & 47884 & 113 & 14168 & 20234 & 1157 & 4167 \\
\hline$Y \cos 15 h$ & 336,046 & 13,026 & 140,28 & 152,656 & 28,686 & 94,362 \\
\hline$Y \sin 15 h$ & $-100,388$ & 7,83 & 105,104 & 143,878 & 44,686 & $-50,82$ \\
\hline $\mathrm{m}$ & 38,33 & 1,58 & 22,67 & 27,50 & 5,25 & 12,75 \\
\hline $\mathrm{b}$ & 56,01 & 2,17 & 23,38 & 25,44 & 4,78 & 15,73 \\
\hline c & $-16,73$ & 1,31 & 17,52 & 23,98 & 7,45 & $-8,47$ \\
\hline $\mathrm{a}$ & 58,453 & 2,534 & 29,214 & 34,962 & 8,850 & 91,209 \\
\hline K & $22.53^{\prime} 24^{\prime \prime}$ & $03.56 ' 24 "$ & $03.32^{\prime} 24^{\prime \prime}$ & $03.7^{\prime} 12^{\prime \prime}$ & $02.10^{\prime} 48^{\prime \prime}$ & $22.6 ' 36 "$ \\
\hline $\mathrm{F}$ & 18,92 & 7,80 & 15,99 & 17,26 & 11,87 & 57,10 \\
\hline D & 152,49 & 160,04 & 128,89 & 127,13 & 168,57 & 715,36 \\
\hline
\end{tabular}

Penelitian periodisitas pada keenam penderita yang diambil darahnya di Kelurahan Pabean Kota Pekalongan menunjukkan mikrofilaria yang ditemukan adalah W.bancrofti. Hal tersebut sesuai dengan ciri W.bancrofti mempunyai sarung / sheath, ujung anterior membulat / tumpul dengan 2 buah stylet (alat pengebor), ujung posterior runcing, perbandingan ruang kepala dengan panjang : lebar yaitu $1: 1$, inti terlihat kasar, tersusun teratur sampai ujung posterior, tidak ada inti pada ujung ekor (da Rocha et al, 2017).

Perhitungan dengan formulasi rumus Aikat dan
Das diperoleh Harga $F$ yang diperoleh pada enam penderita menunjukkan harga $F$ lebih besar daripada harga $\mathrm{F}$ teoritis dengan derajat kebebasan 2 dan (n-3). Nilai-nilai ini menunjukkan bahwa W.bancrofti di Kelurahan Pabean Kota Pekalongan memiliki gelombang harmonik, ritmik atau sirkadian. Kriteria tersebut menunjukkan sifat periodistas W.bancrofti bersifat periodik. Selanjutnya yang perlu diperhatikan adalah nilai K (waktu puncak kepadatan mikrofilaria). Nilai $\mathrm{K}$ ditemukan mulai pada tengah malam yaitu antara pukul $22^{\circ} 6^{\prime} 36^{\prime \prime}$ sampai $03^{\circ} 56^{\prime} 24$ ". 


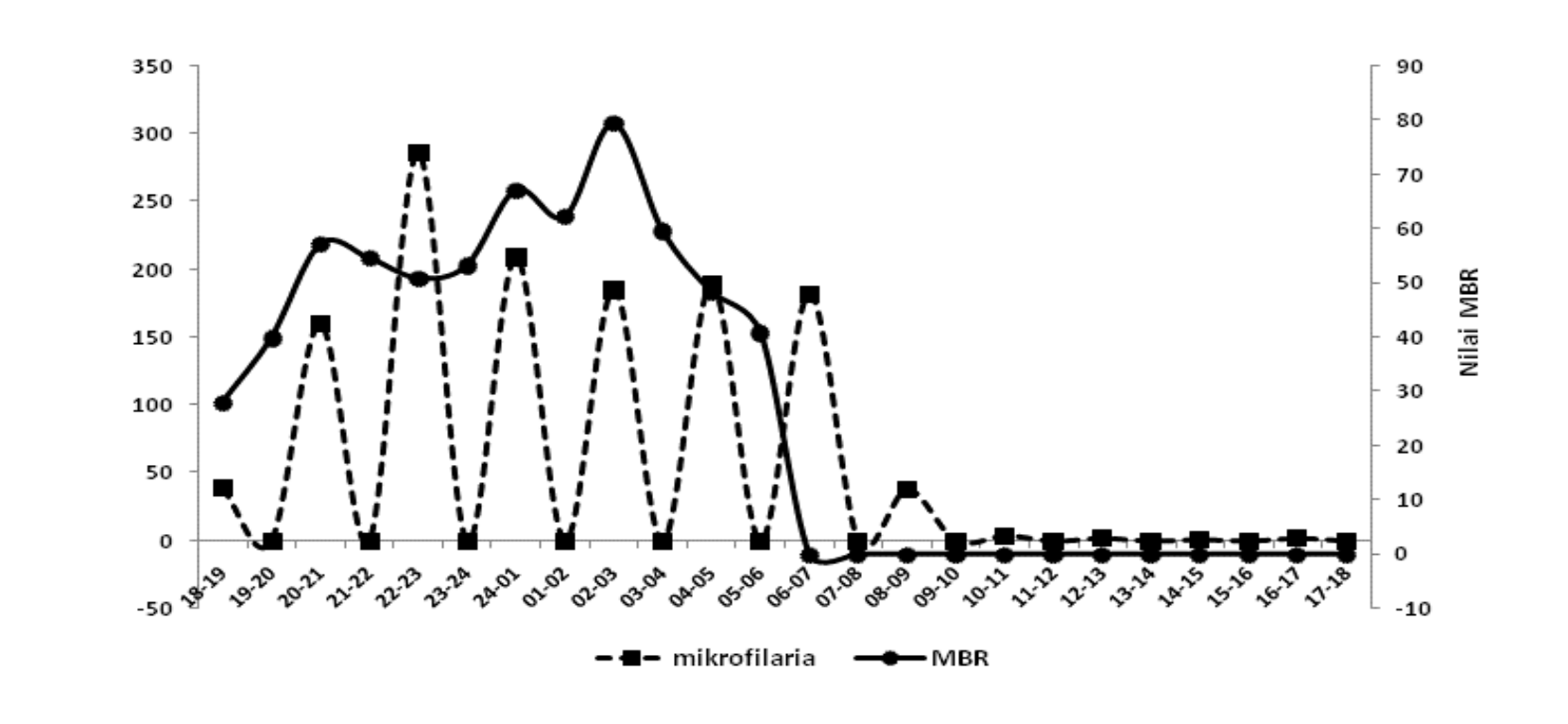

Grafik 2 Fluktuasi aktifitas menggigit Culex quinquifasciatus dengan kepadatan mikrofilaria

Puncak kepadatan mikrofilaria pada keenam kasus filariasis ditemukan malam hari. Harga $\mathrm{K}$ yang ditemukan di semua kasus, dapat dipastikan W.bancrofti yang bersifat periodik noktural karena munculnya kepadatan mikrofilaria sebagian besar pada tengah malam hari. Periodik nokturna yaitu bila kepadatan mikrofilaria ditemukan tinggi pada malam hari dan hampir tidak ada pada siang hari (WHO, 2013;Chadijah et al. 2015)

Hasil penelitian menunjukkan sifat periodik nokturnal W. bancrofti yang berarti bahwa penularan filariasis limfatik di Kelurahan Pabean terjadi pada malam hari. Hal ini merupakan hasil adaptasi yang terjadi antara perilaku nyamuk vektor ( $C x$. quinquefasciatus) yang menggigit pada malam hari dengan perilaku mikrofilaria yang bersifat nokturnal (Sudjadi 1996). Kondisi ini sama dengan filariasis limfatik di India dan negara-negara endemik lain di dunia kecuali daerah Pasifik (Khan AM et al. 2015).

Bentuk periodik nokturnal W. bancrofti di Kelurahan Pabean Kota Pekalongan memberikan dasar pola periodisitas yang lazim di Indonesia. Filariasis limfatik yang disebabkan oleh W.bancrofti prevalensinya cenderung meningkat karena vektor Cx.quinquefasciatus yang mudah berkembang biak di air yang kotor. Kondisi geografis Kelurahan Pabean yang cenderung menggenang (aliran air tidak lancar) mengakibatkan keberadaan nyamuk $C x$. quinquefasciatus tetap terjaga.

Puncak kepadatan mikrofilaria sangat erat hubungannya dengan perilaku nyamuk $C x$. quinquefasciatus yang diketahui sebagai vektor filariasis di Kelurahan Pabean. Ramadhani et al. (2009) melaporkan, aktivitas menggigit $C x$. quinquefasciatus cenderung di dalam rumah pada malam hari. Puncak aktifitas menggigit nyamuk $C x$. quinquefasciatus terjadi pada pukul $20 .{ }^{\circ 0}-21 .^{00}$ dan $24 .^{00}-01 .^{00}$ serta pada tengah hari pukul $02 .^{00}-03 .^{\circ 0}$. Kondisi ini sejalan dengan puncak kepadatan mikrofilaria di darah tepi pada keenam kasus filariasis limfatik di Kelurahan Pabean Kota Pekalongan (Tabel 3).

Perilaku mikrofilaria dalam darah tepi yang berbeda disebabkan karena adanya kadar zat asam dan zat lemas di dalam darah, aktivitas hospes, irama sirkardian, jenis hospes, dan jenis parasit (Kementerian Kesehatan RI, 2015). Cacing penyebab filaria memiliki periodisitas yang berbeda terkait dengan perilaku vektor, siklus sikardian inang serta wilayah kasus (Haryuningtyas dan Subekti, 2004). Periodisitas mikrofilaria juga dipengaruhi oleh tekanan oksigen pada arteri dan vena, kegiatan inang serta aktivitas menggigit vektor (Taniawati et al. 2002).

Periodisitas nokturna menunjukkan bahwa pada siang hari mikrofilaria berkumpul dalam darah kecil paru-paru sedangkan pada malam hari mikrofilaria dilepaskan ke pembuluh darah tepi (Natadisastra dan Agoes, 2009).

Mikrofilaria pada tubuh manusia dapat terus melangsungkan kehidupannya, apabila terhisap oleh nyamuk. Sehingga secara alami mikrofilaria akan mengumpankan dirinya dan berada di darah tepi pada waktu-waktu tertentu, sesuai dengan perilaku nyamuk (Beriajaya. 2009). Spesies nyamuk vektor yang sesuai dapat berhasil meneruskan siklus hidupnya, sehingga mikrofilaria mempunyai relung ekologik (niche maupun subniche) sendiri yang benar-benar cocok untuk masing-masing spesies. B.malayi subperiodik nokturnal, dapat berkembang 
optimal di daerah hutan yang terbuka (open swamp) dengan nyamuk Mansonia uniformis sebagai vektornya (Sudjadi 1999). Pada B.malayi periodik nokturnal, kecocokan lingkungan itu telah bergeser ke daerah pertanian atau persawahan, dimana disesuaikan dengan kehidupan nyamuk An.barbirostris. sebagai vektornya.

Kecenderungan adaptasi nyamuk yang menggigit pada malam hari, adaptasi filaria lebih menunjukkan arah dari dalam keluar hutan ataupun dari rural ke arah urban. Kondisi ini mengakibatkan W.bancrofti perkotaan lebih mudah menyebar kembali ke pedesaan daripada W.bancrofti pedesaan ke perkotaan, sama seperti ditunjukkan oleh Wharton di Malaysia (Sudjadi 1996).

Windiastuti et al (2013) melaporkan keberadaan tempat perkembagbiakan, kebiasaan masyarakat keluar malam dan tidak menggunakan anti nyamuk merupakan faktor risiko penularan limfatik di Kota Pekalongan. Berdasarkan kebiasaan masyarakat dan periodisitas dari W.bancrofti yang telah diketahui, maka upaya penanggulangan filariasis limfatik dengan cara menghindari kontak dengan nyamuk terutama malam hari. Pengendalian filariasis limfatik merupakan tanggung jawab bersama antara pemerintah dan masyarakat, sehingga peran serta masyarakatsangat menentukan keberhasilan eliminasi di tingkat kabupaten atau kota (Yahya and Santoso, 2013).

Kepadatan puncak mikrofilaria pada keenam kasus filariasis limfatik terjadi pada malam hari. Waktu puncak kepadatan (nilai K) ditemukan mulai pada tengah malam yaitu antara pukul $22^{\circ} 6^{\prime} 36^{\prime \prime}$ sampai 03.56'24, dapat dipastikan W. bancrofti bersifat periodik nokturna karena munculnya mikrofilaria cenderung pada malam hari serta dapat dilihat dari ritme variasi kepadatan mikrofilaria (F) yang sirkadian.. Puncak kepadatan mikrofilaria sejalan dengan puncak kepadatan dan aktivitas menggigit nyamuk $C x$. quinquefasciatus sebagai vektornya.

Periodisitas mikrofilaria periodik mengindikasikan perlu kewaspadaan terhadap gigitan nyamuk vektor pada malam hari. Kelurahan Pabean Kota Pekalongan masih endemis filariasis limfatik dengan kemungkinan masih terjadinya risiko penularan. Perlunya dilakukan penyuluhan kepada masyarakat di daerah penelitian untuk menghindari kontak dengan nyamuk, mengurangi aktifitas di luar rumah pada malam hari dan menghilangkan tempat perkembangbiakan nyamuk $C x$. quinquefasciatus.

\section{UCAPAN TERIMA KASIH}

Penulis menyampaikan ucapan terima kasih kepada Kepala Balai Litbang P2B2 Banjarnegara yang telah memberikan kesempatan untuk melakukan penelitian, juga semua peneliti, teknisi yang telah membantu kelancaran jalannya penelitian. Tak lupa kepada seluruh staf P2P Kota Pekalongan, Kelurahan Pabean serta seluruh pihak yang telah memberikan bantuan dan dukungan guna kelancaran penelitian ini.

"Penulis menyatakan tidak ada konflik kepentingan dengan pihak-pihak yang terkait dalam penelitian ini"

\section{DAFTAR PUSTAKA}

Aikat, Das. 1976. A Modified Statistical Method for analysis of periodicity of Mikrofilariae. WHO/Fil/76; 142:1

Beriajaya. 2009. Peranan vektor sebagai penular penyakit zoonosis Proc. Lokakarya Nasional Penyakit Zoonosis Hal. 275-288

Budi Mulyaningsih, F.A.Sudjadi, 1999,Brugia malayi nonperiodik sebagai Penyebab Filariasis pada Penduduk Asli Dayak Benuak di Pedalaman Kalimantan Timur, Berita Kedokteran Masyarakat XV (3)

Chadijah, S., Rosmini and Srikandi, Y. 2015. Perilaku mikrofilaria Brugia malayi pada subjek Filariasis di Desa Polewali Kecamatan Bambalamotu Kabupaten Mamuju Utara Sulawesi Barat, Jurnal Aspirator, 7(2); 42-47

da Rocha, EMM, Fontes G. and Ehrenberg, JP 2017 'Lymphatic Filariasis', in Arthropod Borne Diseases. Springer, pp. 369-381

Dinkes Kota Pekalongan, 2012 Laporan P2P DinasKesehatan Kota Pekalongan. Pekalongan: Dinas Kesehatan Kota Pekalongan Download: Januari 25, 2018

Haryuningtyas S.D, Subekti DT. 2004. Dinamika filariasis di indonesia. Lokakarya Nasional Penyakit Zoonosis. 2004: 242-250. http: //digilib. litbang.deptan.go.id/repositor y/index.php/repository/

Kementerian Kesehatan Republik Indonesia [Kemenkes RI] 2010, Buletin Jendela Epidemiologi, Volume 1

Kementerian Kesehatan Republik Indonesia [Kemenkes RI] 2014, Panduan Pemeriksaan Lymphatic Filariasis Dengan Metode Survei Darah Jari, Subdit Filariasis dan Kecacingan, 
Ditjen P2PL, Kementerian Kesehatan RI, Jakarta

Kementerian Kesehatan Republik Indonesia [Kemenkes RI] 2015. Peraturan Menteri Kesehatan Repubik Indonesia Nomor 94 tahun 2014, tentang Penanggulangan Filariasis. Jakarta: Kementerian Kesehatan RI

Khan AM, Dutta P, Das S, Pathak AK, Sarmah P, Hussain ME, Mahanta J, 2015 Microfilarial Periodicity of Wuchereria bancrofti in Assam, Northeast India, J Vector Borne Dis. ;52(3):208- 12.

Kota Pekalongan 2015, Profil Kelurahan Pabean http://www.pabean.pekalongankota.or.id/

Mac Donald ,W.W.1976. Mosquito genetics in relation to filarial infections. pp.1-24 In:Taylor,A.E.R. and Muller,R. (ed.) Genetic aspects of host-parasite relationships Symposia of the British Society for Parasitology, Vol.14). Oxford, Blackwell

Natadisastra D, Agoes R. 2009. Parasitologi Kedokteran- Ditinjau Dari Organ Tubuh Yang Diserang. Penerbit EGC

Partono,F \& Purnomo, 1987. Periodicity studies of Brugia malayi in Indonesia : recent findings and modified classification of the parasite. Trans. Roy. Sec. Trop. Med. Hyg. 81: $657-662$

Pusdatin Kemnkes RI 2016,Situasi Filariasis di Indonesia Tahun 2015, Infodatin ISSN 24427659

Ramadhani T dan Yunianto B, 2009, Aktivitas Menggigit Nyamuk Culex quinquefasciatus Di Daerah Endemis Filariasis Limfatik Kelurahan Pabean Kota Pekalongan Provinsi Jawa Tengah, Jurnal Aspirator Vol. 1 No. 1 page : 11-15

Ramadhani T, Bambang Yunianto 2008, Studi Periodisitas Mikrofilaria Wuchereria bancrofti di Kelurahan Pabean Kota Pekalongan, makalah seminar nasional parasitik jaringan di Donggala

Ramadhani T, Suyoko, Sri Sumarni, 2010, Culex quinquefasciatus sebagai vektor utama filariasis limfatik yang disebabkan wuchereria bancrofti di Kelurahan pabean Kota Pekalongan, Jurnal Ekologi Kesehatan Edisi 9 Vol 3

Santoso, 2010, Periodisitas Parasit Filariasis Di Desa Karya Makmur Kecamatan Lubuk Rajam Kabupaten Oku Timur Pada Tahun 2007, Jurnal Ekologi Kesehatan Vol. 9 No 1, 1178-1184
Sasa, M. 1976. Human Filariasis. A Global Survey of Epidemiology and Control. Tokyo: University of Tokyo Press

Sudjadi FA, 1996, Habitat alami Brugia malayi nonperiodik penyebab filariasis di Kalimanatan Timur, Berita Kedokteran Masyarakat XII: 19- 22

Sudjadi, F.A. 1996. Filariasis di beberapa daerah endemik di Kalimantan Timur. Kajian intraspesifik Brugia malayi penyebab penyakit dan beberapa aspek epidemiologinya (Disertasi). Universitas Gadjah Mada, Yogyakarta

Sunaryo, Ramadhani T, 2008, Distribusi Filariasis Limfatik di Kelurahan Pabean Kecamatan pekalongan Utara Kota Pekalongan, Jurnal Balaba Ed 001 No 02 Desember 2008

Taniawati Supali, Is Suhariah Ismid, Paul Ruckertand Peter Fischer, 2002, Treatment of Brugia timori and Wuchereria bancrofti infections in Indonesia using DEC or a combination of DEC and albendazole: adverse reactions and short-term effects on microfilariae, Jurnal Tropical Medicine and International Health volume 7 no 10 pp 894-901

WHO. 1982. Manual on environmental management for mosquito control. Geneva, World Health Organization, Offset Publication No. 66, $283 \mathrm{pp}$.

WHO 1986. Technical Report Series, No. 737. (Resistance of vectors and reservoirs of disease to pesticides: tenth report of the WHOExpert Committee on Vector Biology and Control). Geneva, World Health Organization, $87 \mathrm{pp}$

WHO 2013 Vector Biology and Profile in Global Programme to Eliminate Lymphatic Filariasis

Windiastuti, Ani I, Suhartono, Nurjazuli, 2013, Hubungan Kondisi Lingkungan Rumah, Sosial Ekonomi, dan Perilaku Masyarakat dengan Kejadian Filariasis di Kecamatan Pekalongan Selatan Kota Pekalongan Jurnal Kesehatan Lingkungan Indonesia Vol.12(1): 51-57

Yahya and Santoso. 2013. Studi Endemisitas Filariasis di Wilayah Kecamatan Pemayung Kabupaten Batanghari Pasca Pengobatan Massal Tahap III, Buletin Penelitian Kesehatan Vol 41(1);18-25 